\title{
A study of crop-to-crop gene flow using farm scale sites of fodder maize (Zea mays L.) in the UK
}

\author{
Rebecca Weekes · Theodore Allnutt • \\ Caroline Boffey · Sarah Morgan · Mark Bilton • \\ Roger Daniels $\cdot$ Christine Henry
}

Published online: 27 March 2008

(C) Springer Science+Business Media B.V. 2008

\section{Erratum to: Transgenic Res (2007) 16: 203-211 DOI 10.1007/s11248-006-9036-0}

Due to an unfortunate mistake, an incorrect version of Fig. 2 has been used in the above mentioned publication. The $y$-axis scale is incorrect as the values in this scale should have been multiplied by 0.58 as described in the text. Correspondingly, the bottom line in the left hand column on p. 207 should have read:

'...recorded was $38 \%$; the mean value was $4.8 \%$.'

The correct representation of Fig. 2 is published on the following page and should be treated as definitive by the reader. 
Fig. 2 Plot of \%GM DNA as measured in all maize FSE samples versus distance. The dashed line shows the upper 98th percentile and the solid line the mean for the fitted twostep model

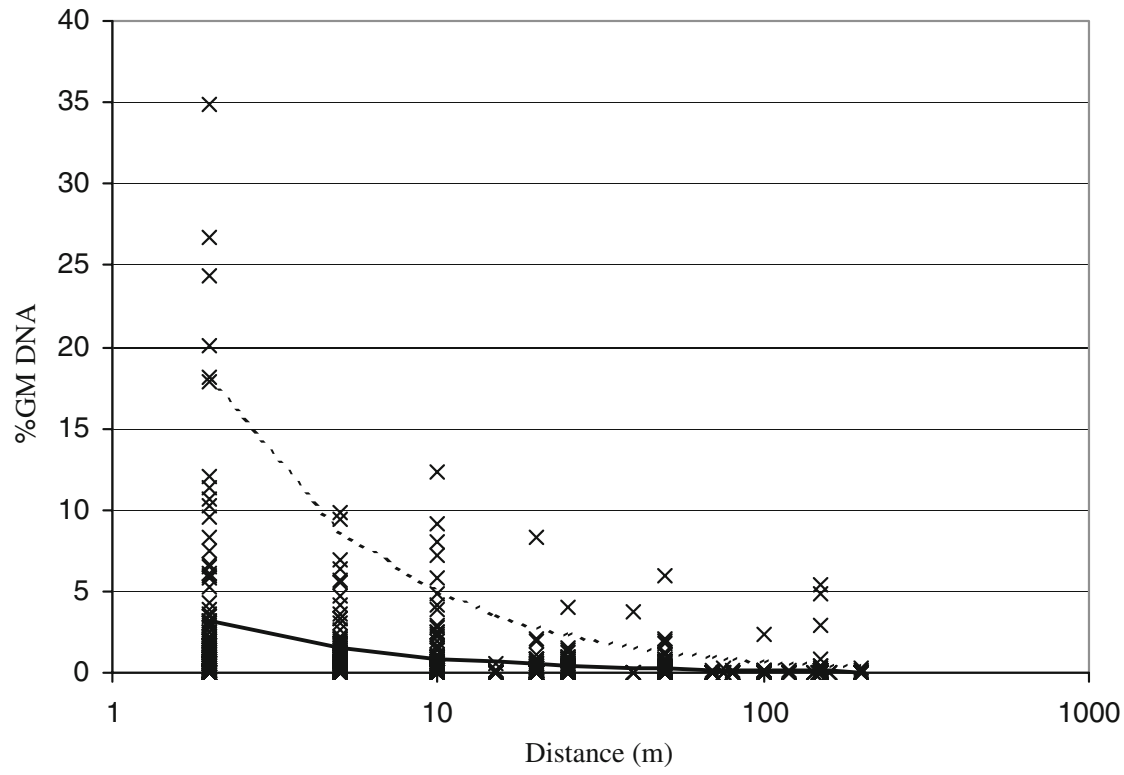

